\title{
The General Election Commission (KPU) Communication Model in Increasing Voter Participation in the Election of the Governor of Sumut 2018 in Labuhanbatu Selatan District
}

\author{
Sarino $^{1}$, Erwan Efendi ${ }^{2}$, Anang Anas Azhar ${ }^{3}$ \\ 1,2,3 Universitas Islam Negeri Sumatera Utara, Indonesia \\ massarino17@gmail.com
}

\begin{abstract}
This study aims to find out The General Election Commission (KPU) Communication Model in Increasing Voter Participation in the Election of the Governor of Sumut 2018. This research is included in qualitative research. Qualitative research is a social research which fundamentally relies on observing humans in their own domain and relating to those people who seek toreveal actual facts / phenomena that occur in the field. Based on the results of research that has been carried out with the title "Communication Model of the General Election Commission (KPU) in Increasing Voter Participation in the 2018 North Sumatra Governor Election in South Labuhanbatu Regency", the researchers concluded as follows: The General Election Commission of South Labuhanbatu Regency will collect data on the List of Candidates for Permanent Voters who will be given outreach. The General Election Commission of South Labuhanbatu Regency conducts outreach for novice voter candidates in high school equivalent to students who are already in class XII The General Election Commission of South Labuhanbatu Regency carried out the dissemination of the Governor Election to Farmers and Fishermen Communities. The General Election Commission of South Labuhanbatu Regency Strengthens the Synergy of the General Election Commission (KPU) with Local Community Organizations (Ormas). The General Election Commission of South Labuhanbatu Regency conducted socialization through audio and visual media. The General Election Commission of South Labuhanbatu Regency uses the Question and Answer method, the community asks questions related to procedures and so on then the officer answers or vice versa
\end{abstract}

Keywords

general election commission;

communication, voter participation

\section{Introduction}

Election implementation can run as expected if there is socialization to the public as voters. This socialization aims to invite the public to participate in the implementation of elections and other political activities related to government decision making. Whereas political socialization is defined as a process of how to introduce a political system to a person and how that person determines his responses and reactions to political symptoms.Based on a broader scope, political socialization in each individual has actually occurred consciously or unconsciously. continuously happens to someone from children, adults, to old people. Political socialization is also determined by the social environment.

Political socialization of a person beginning in childhood usually results from his interactions with socialization agents. Socialization agents are individuals or groups who directly or indirectly provide an initial introduction to politics to someone. Political 
socialization agents are usually in a scope close to a person's life and are directly concerned with the process of understanding politics. The closest socialization agent is the family where a child has more intensity with the family. There are at least three agents of socialization that influence a person's political attitudes, namely family, school and workplace. Apart from that, there are social groups, mass media and direct political contacts which can have an effect on the nature and reactions regarding politics.

Political socialization is a series of processes consisting of knowledge, values, and attitudes which are channeled by individuals and groups of individuals in a political system to then shape an individual's political behavior. Some of the stimuli in socialization are acceptable while others are rejected in such a way that political behavior, especially in terms of political participation, differs from one individual to another.

In every election, there is usually an additional number of voters. The increase in the number of voters is an indicator of an increase in the number of first-time voters. Postreform elections want to answer demands for a more democratic government with periodic changes of power. In addition, the presence of the General Election for Regional Heads itself is to end the centralization of power in the New Order Era. Many parties believe that the Pemilukada will be a political answer to various downturns and inequalities in various fields (especially the economy) in the regions for decades; as well as an entry point for the development of a more stable and prosperous political system with a fairly large distribution of power and authority to the regions, it is hoped that regional development will be faster and in line with the expectations of the community.

Both election and post-conflict local elections have their own notes that should be noted. Recently, the trend of both elections and post-conflict local elections has tended to emerge in the decline in participation rates. In elections that have been held in Indonesia, the level of voter participation has decreased over time. More and more citizens who have voting rights do not use their voting rights in elections (golput). Ndemocratic state means a state which has a form of government from the people, by the people and for the people. Indonesia is one of the countries in the world that adheres to democracy. In this understanding the people have a very important position, because sovereignty is in the hands of the people. This means that the people are sovereign, have the power to determine how they should be governed. The implementation of quality general elections is needed as a means of realizing the sovereignty of the people in the democratic state government of Pancasila and the 1945 Constitution of the Republic of Indonesia. integrity, capability and accountability.

Voter participation in elections is one of the benchmarks of the success of political development. The high level of voter participation will indicate the success of the elections and the low voter participation will indicate the failure of the election. Therefore, it is necessary to increase the participation of the voters as the responsibility of the KPU. Therefore, the KPU makes an effort to increase voter participation by conducting election socialization in Langkat Regency. The socialization aims to provide and disseminate information on elections. (Amrizal et al, 2018)

Politics in general is one of the sciences of state / state structure, as a collective word that shows thoughts that aim to gain power. Politics is often interpreted as power. Meanwhile, political communication is seen as a political tool (political mean) to achieve goals. Political communication has bridged two disciplines in social science, namely communication and politics. Every political system, political outreach and recruitment, interest groups, rulers, regulations, and so on are considered to have communication content.Indonesia is one of the countries in the world that adheres to a democratic system which in its application wants the widest possible freedom of political participation for all 
people to take an active role in determining the direction of national development. One of its roles is to determine the leader directly, publicly, freely and secretly through a general election. To achieve this, the government is required to be able to facilitate the holding of elections as an effort to build democracy.

Political events always get attention and spotlight from the mass media including newspapers as material for coverage. Brian McNair explains: "There are two factors that make political events become the attention of the mass media. First, today politics is in the era of mediation, namely the mass media, so it is almost impossible for political life to be separated from the mass media. In fact, political actors always try to attract journalists' attention so that their political activities get coverage from the media. Second, political events in the form of behavior and statements of political actors usually always have news value even though political events are routine in nature, for example a party meeting or a meeting of a political figure with his supporters (Hamad in Rudanto, 2021).

Political parties, namely political organizations that carry out certain ideologies or are formed with special objectives. Another definition is an organized group whose members have the same orientation, values and ideals. Meaccording to the Law of the Republic of Indonesia No. 2 of 2008 concerning political parties. Political parties are political organizations that are national in nature and are formed by a group of Indonesian citizens voluntarily based on the same will and aspirations to fight for and defend the political interests of members, society, nation and state and maintain the integrity of the Republic of Indonesia based on Pancasila and the 1945 Constitution.

\section{Research Methods}

This research is included in qualitative research. Qualitative research is a social research which fundamentally relies on observing humans in their own domain and relating to those people who seek toreveal actual facts / phenomena that occur in the field. It is said that because this type of research has characteristics including the actual setting, the researcher is the key instrument, the data is descriptive, emphasizes the process, the data analysis is inductive, and the meaning (meaning) of each event is an essential concern in qualitative research. He said the facts because they match what happened in the field. The research objective is to describe social events, by disclosing factual events in the field and revealing hidden values, being more sensitive to descriptive information and trying to maintain the integrity of the object under study.

Based on Approach the above, the approach of this research is a descriptive analytical approach. Analytical descriptive approach aims to describe, describe, systematically describe the facts or characteristics of a particular population or particular field factually and accurately. This approach also aims to obtain an in-depth description of speech, writing and behavior that can be observed from an individual or community group or organization in a setting. Which is examined from a comprehensive point of view.

\section{Results and Discussion}

\subsection{Determine the List of Prospective Voters Who Will Be Given the Socialization}

Data collection on the number of lists of permanent voters is a process of recording, calculating, and publishing data carried out on all residents who live permanently in a certain region or country simultaneously or in stages. Data collection on the number of voter lists is still carried out by the General Election Commission of South Labuhanbatu Regency which is carried out gradually day after day before the North Sumatra 
gubernatorial election. Data collection was carried out to the edge of the village, assisted by sub-district officials to village officials, which can be interpreted as a whole process from collecting, processing, assessing, analyzing, and presenting data and population data relating to name, gender to age.

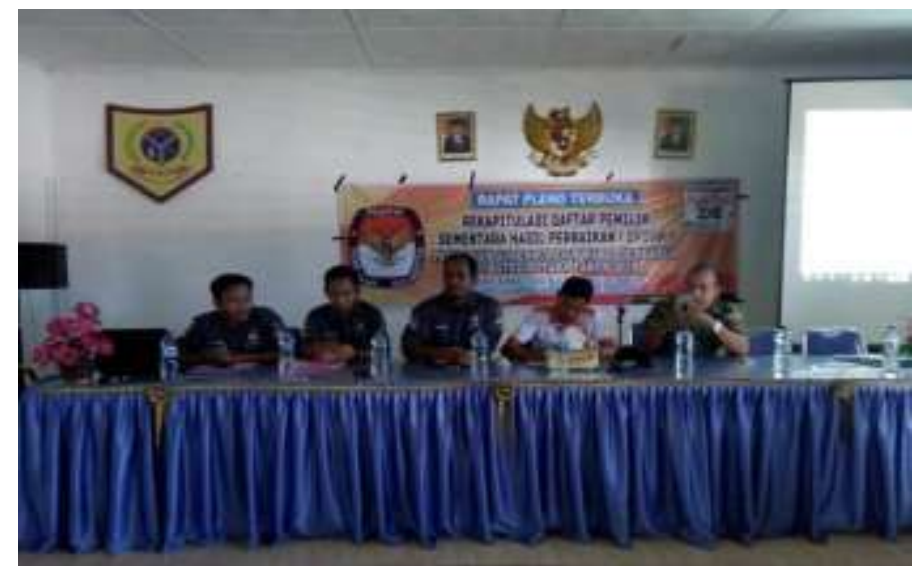

Figure 1. Recapitulation of Voters List in Kab. South Labuhanbatu Source: KPUD District Secretariat. South Labuhanbatu

\subsection{Socialization of New Voters Candidates to high school students and equivalent.}

Students or adolescents generally have a social system that seems to describe them as having "their own world". In this adolescent system there is a culture which, among other things, has values, norms. Attitude and language apart from adults. Thus adolescents generally have similarities in behavior patterns, attitudes and values, where this collective behavior pattern can differ in several ways from adults.

Puberty is the initial stage of the development of social feelings. At this time, the desire of adolescents to have close friends and an attitude of unity with their friends arises, while they distance themselves from adults. This "peer culture" is very influential during adolescence so that the values of the peer group influence their behavior. A teenager needs support and consensus from his peer group. In this case, any deviation from group values and norms will be criticized by the group, because the relationship between adolescents and their group is solidarity and loyal friends. In general, adolescents form smaller groups based on similarities in interest, pleasure or other factors. With regard to the cultural capacity of these youth / students, at least it can be used as an important illustration of the effort to see the map of democracy and political awareness among teenagers in the school environment as part of the first-time voters in the elections. So, there are three levels of material that need to be embedded in the educational curriculum relating to the socialization of elections through the educational curriculum. The three materials are planting the essence of the correct election so as to generate strong motives for new voters to participate in elections, an understanding of the electoral system, and an understanding of political bargaining positions. 


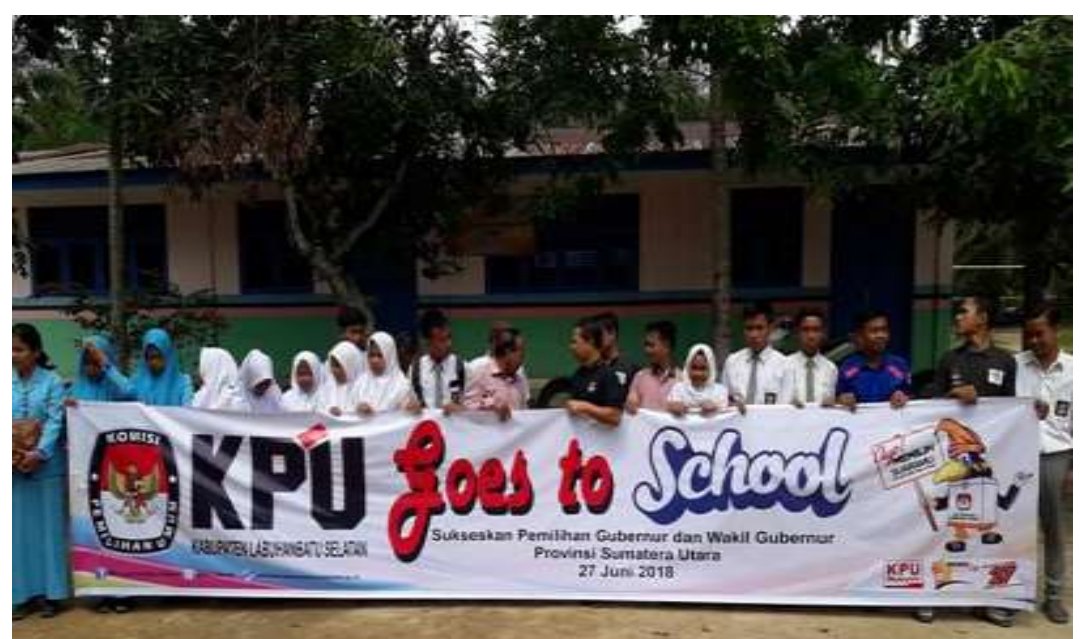

Figure 2. Socialization of Candidates for Beginner Voters at SMAN 1 Kotapinang Source: KPUD District Secretariat. South Labuhanbatu

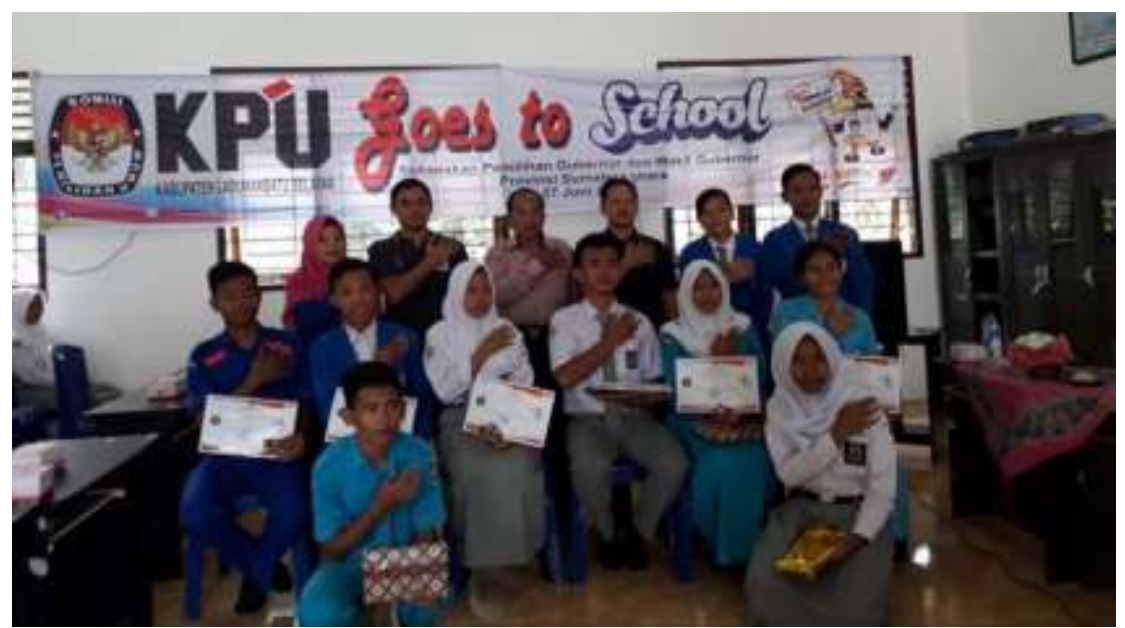

Figure 3. Socialization of Candidates for Beginner Voters at SMKN 1 Silangkitang Source: KPUD Secretariat of South Labuhanbatu Regency

\subsection{Socialization of Governor Election to Farmers and Fishermen Communities}

Socialization is one of the important aspects in the social contact process because in order to influence people to behave in accordance with applicable legal principles, it takes an awareness that arises in a person to obey and implement the rules that have been published. This awareness can be grown through various ways such as preaching, notification, education, and teaching. Through these methods, it is hoped that someone will become aware of what the normative content is contained in the rules that have been conveyed. Then after someone knows the substance that has been conveyed, he will try to adjust all his behavior with these demands.

In this study, researchers have interviewed the Commissioner for the General Election Commission of South Labuhanbatu Regency named M. Anshori, S.Pd, his position is the Planning and Data Division at the General Election Commission of South Labuhanbatu Regency. Based on the explanation given by M. Anshori, S.Pd, his position is the Planning and Data Division at the General Election Commission of South Labuhanbatu Regency that the communication delivered to farmers and fishermen is in the form of rules or regulations for the 2018 regional election. The South is binding and if there is an 
element of violation of the law then it will be subject to administrative sanctions to criminal sanctions, so in this case it is necessary to be careful in acting so that violations can be prevented.

Pemilh in this type has a very high ideological orientation and does not really see the policies of political parties or contestants as important in decision making. Traditional voters prioritize socio-cultural closeness, values, origins, beliefs and religions as a measure for choosing a political party. Policies such as economy, welfare, equal distribution of income and education, and reduction of the inflation rate are considered as the second parameter. They don't worry too much about what policies have been implemented and what the political parties they support will do. Usually this type of voter prioritizes the leaders' figures and personalities, the myths and historical values of a political party or a contestant.

On the other hand, there are some individuals who are fishermen and farmers who are partly skeptical about the 2018 North Sumatra gubernatorial election. Farmers and fishermen who are skeptical of the 2018 North Sumatra governor election are actually farmers and fishermen whose backgrounds are marginalized. PemilThese are voters who do not have a high enough ideological orientation with a political party or a contestant, nor do they make policy important. These types of voters are very less willing to be involved in a political party, because their ideological ties are indeed very low. They also pay less attention to the platform and policies of a political party. The white group (golput) in Indonesia or anywhere else is very much dominated by this type of voter. Even if they participate in voting, they usually do it randomly. They believe that whoever or any party that wins the election will not be able to lead the nation to the improvement they hope for.

\subsection{Strengthening the Synergy of the General Election Commission (KPU) and Local Community Organizations (Ormas)}

To carry out the state's mandate to carry out regional head elections, namely the election of a democratic North Sumatra governor, is a tough task, so to carry out this task the General Election Commission of South Labuhanbatu Regency is making extra and concrete efforts to support the success of the North Sumatra governor election in 2018. The synergy of the General Election Commission of South Labuhanbatu Regency needs to be built. Synergy with local community organizations, election administration institutions require communication between community organization leaders. The background for the formation of this forum departs from an understanding that in order to maintain the stability of close relationships,

The General Election Commission of South Labuhanbatu Regency cannot work alone, but like it or not, it must involve the participation of community organizations. Moreover, in the current era of reformation, regional head elections which are a manifestation of the progress of a democratic country, of course, become a country that remains consistent in realizing democracy in this country. Regional head elections are a representative form of a developed country, therefore general elections have become the main element in the reform era that was built in 1998 until now. The General Election Commission of South Labuhanbatu Regency as an instrument of a neutral and independent state to realize an even general election. According to the description Zulham Dani Rambe, $\mathrm{SH}$ which is the General Division of Finance and Logistics at the General Election Commission of South Labuhanbatu Regency, he conveyed to researchers in an unstructured question and answer session.

Based on the statement submitted by Zulham Dani Rambe, $\mathrm{SH}$ which is the General Division of Finance and Logistics at the General Election Commission of South 
Labuhanbatu Regency, the Synergy of the General Election Commission of South Labuhanbatu Regency and the Community made a tremendous contribution to the appeal process, this achievement was made because of the optimal synergy between the organizers of the 2018 governor election and the local community. through small forums capable of having a tremendous impact on success, so that herizontal and vertical conflicts can be mitigated through approaches to mass organizations in South Labuhanbatu Regency



Figure 4. The Synergy of the General Election Commission of South Labuhanbatu Regency with Community Organizations

Source: South Labuhanbatu Regency General Election Commission Secretariat Office

\subsection{Delivering motivational messages on the importance of the election for the governor of North Sumatra}

Lots of people, even it is common for people to call "motives" to show why someone is doing something Motivation and motivation are closely related to appreciating a need. The word "motive" is defined as an effort to encourage someone to do something. Motivation is something that encourages someone to act to do something. Or a complex statement in an organism that directs behavior / action to a goal or motivational stimulant or impulse is a complex condition in an organism that directs behavior towards a goal (goal) which determines or limits the organism's behavior., then we use the term "incentive" (incentive). The goal (goal) is what determines or limits the behavior of the organism. If what is emphasized is the fact / object, which attracts the organism, then we use the term "stimulant".

This research, researchers will dig deeper into the importance of providing motivation to people who have voting rights in political contestation, namely the 2018 North Sumatra gubernatorial election. The researcher quoted a statement made by the head of the General Election Commission of South Labuhanbatu Regency, namely Sumarno, who is also a senior figure in the General Election Commission of South Labuhanbatu Regency in a discussion session with the researcher. Based on the statement conveyed by the Head of the General Election Commission of South Labuhanbatu Regency named Sumarno, SE, the researcher concluded that motivational messages really need to be conveyed to the community so that people can be physically and spiritually motivated to transfer their voting rights to the nearest polling places. has been provided by the General Election Commission of South Labuhanbatu Regency. 


\subsection{Socialization through Media}

In the midst of the current digital era, media in cyberspace has become a medium for socializing with each other and is carried out simultaneously which allows people to know each other's information without being limited by space and time. Media remove human boundaries to obtain information, space and time. Because with the media, it is possible for humans to motivate others.

Everyone has an event or problem that happened to him or an experience that made him eventually motivated. This will be different for each individual even though they see the same thing. Hedonism is also one of the motivators, fear, worry about his survival to avoid murder. If he thinks of winning he doesn't hesitate to attack, he will do whatever is best for himself. Motivation is one of the topics that is often discussed but rarely broadcast on television in an Islamic perspective. Because so far, motivation is often given based on Western theories and concepts. Motivation is an encouragement to the behavior of organisms that continue to carry out activities stimulated by an incentive. This kind of behavior is manifested due to physiological stress (need for drinking) or psychology, (appreciation) is leading to the attainment of something matlamat. If you feel thirsty, it requires your drink to be motivated (driven) to try to find a drink. Your behavior (i.e. trying to find a drink) has an eye, which is to fulfill thirst. The incentive or satisfaction you get because of that effort is a drink. After the achievement of the matrix the organism's motivation will decrease. The incentive or satisfaction you get because of that effort is a drink. After the achievement of the matrix the organism's motivation will decrease. The incentive or satisfaction you get because of that effort is a drink. After the achievement of the matrix the organism's motivation will decrease.

In this study, the researcher will explain the use of media to the socialization of the 2018 governor election, therefore to strengthen the results of this study the researcher entered a statement submitted by the General Election Commission of South Labuhanbatu Regency, his name was Ir. M. Ali Nababan who is a member of the KPUD Kab. South Labuhanbatu in the field of Legal Division at the General Election Commission of South Labuhanbatu Regency.

\section{Conclusion}

Based on the results of research that has been carried out with the title "Communication Model of the General Election Commission (KPU) in Increasing Voter Participation in the 2018 North Sumatra Governor Election in South Labuhanbatu Regency", the researchers concluded as follows:

1. The General Election Commission of South Labuhanbatu Regency will collect data on the List of Candidates for Permanent Voters who will be given outreach.

2. The General Election Commission of South Labuhanbatu Regency conducts outreach for novice voter candidates in high school equivalent to students who are already in class XII

3. The General Election Commission of South Labuhanbatu Regency carried out the dissemination of the Governor Election to Farmers and Fishermen Communities.

4. The General Election Commission of South Labuhanbatu Regency Strengthens the Synergy of the General Election Commission (KPU) with Local Community Organizations (Ormas).

5. The General Election Commission of South Labuhanbatu Regency conducted socialization through audio and visual media. 
6. The General Election Commission of South Labuhanbatu Regency uses the Question and Answer method, the community asks questions related to procedures and so on then the officer answers or vice versa

7. The General Election Commission of South Labuhanbatu Regency has taken a persuasive approachby persuading, inviting, or seducing so that the public can flock to hand over their voting rights to the nearest polling stations that have been provided by the officer.

8. South Labuhanbatu Regency General Election Commission Providing socialization of ballot polling simulation exercises so that the public understands the implementation mechanism at the polling stations.

9. The community gave a positive response, especially from students because it was the first time that grade XII students had the right to vote.

10. People who live in isolated zone areas give a negative response because not all isolated locations get socialization from the General Election Commission of South Labuhanbatu Regency.

11. The budget for the General Election Commission of South Labuhanbatu Regency is limited so that the number of media for simulation props and supporting facilities for socialization is limited.

12. Low enthusiasm from the farming and fishing communities

13. The limited number of personnel from the General Election Commission of South Labuhanbatu Regency is unable to cover the entire zone of the relatively wide area of South Labuhanbatu Regency.

\section{References}

Alquran dan Terjemahan. (2010). Jakarta: Kemenag RI.

Afifudduin sebani. (2008). Metodologi Penelitian Kualitatif. Bandung: Pustaka Setia.

Ali, Muhammad. (2011). Kamus Lengkap Bahasa Indonesia Modern. Jakarta: Pustaka.

Amiruddin Nursanjaya. (2002). Prosedur Penelitian Suatu Pendekatan Praktek, Jakarta: Rineka Cipta.

Amrizal, D. et al. (2018). The Role of General Election Commission (KPU) in Increasing Voters' Participation in Langkat, Medan, Indonesia. Budapest International Research and Critics Institute-Journal (BIRCI-Journal). P.13-24.

Andre Uta Ujan. (2015). Keadilan Dan Demokrasi Telaah Filsafat Politik. Jakarta : Kencana.

Arikunto, Suharsimi. (2006). Prosedur Penelitian Suatu Pendekatan Praktik. Jakarta: PT. Rineka Cipta.

Arikunto, Suharsimi. (2006). Prosedur Penelitian Suatu Pendekatan Praktik, Jakarta: PT. Rineka Cipta.

Bastian, Indra.( 2007). Akutansi Untuk LSM dan Partai Politik. Jakarta.Erlangga.

Beni, ahmad sebani. (2008). Metodologi Penelitian Kualitatif. Bandung: Pustaka Setia.

Bungin Burhan. (2007). Sosiologi Komunikassi. Jakarta: Kencana.

Bungin,Burhan.( 2003). Metodologi Penelitian Kualitatif Aktualisasi Metodologis

KeArah Ragam Varian Kontemporer, Jakarta: PT.Raja Grafindo Persada.

Bungin, Burhan. (2007). Sosiologi komunikassi. Jakarta: Kencana.

Deddy Mulyana. (2012). Ilmu Komunikasi. Bandung : Remaja Rosdakarya.

Dwiningrum, siti Irene. (2011). Desentralisasi Dan Partisipasi Masyarakat Dalam

Pendidikan. Yoyakarta : PT.Pusaka Pelajar. 
Effendy, Hardjana. (2003). Dinamika Komunikasi Intrapersonal Dan Interpersonal. Yogyakarta: Kanisius.

Hartono. (2006). Kamus Praktis Bahasa Indonesia Terpadu. Jakarta: Rineka cipta,.

Hatta, Mohammad. Demokrasi Kita Dan Pikiran- pikiran tentang Demokrasi dan Kedaulatan Rakyat. Bandung: Sega Arsy, 2009.

Hikam, Politik Kewarganegaraan Landasan Redemokratisasi di Indonesia, Jakarta: Kencana, 2015.

Haryanto. (2005). ignatius. Pers Lokal Dan Pilkada Langsung. Jakarta : Penerbit Kompas. Imam, As'ari Syafari. (2006). Sosiologi Kota Dan Desa. Surabaya: Usaha Nasional.

John, Lofland dan Lyn H. Lofland. (1984). Anliyzing Social Setting: A Guide to Qualitative Observation andAnalysis. Belmont: Wadsworth Publishing Company.

Joko, Subagyo. (2009). Metode Penelitian Dalam Teori Dan Praktek, Jakarta: P.T Rineka Cipta.

Julia, T. Wood. (2009). Communication in Our Lives, USA: University of North Carolina at Capital Hill.

Kabupaten Labuhan Batu Selatan dalam angka tahun 2017.

Komisi Pemilihan Umum. Rekapitulasi Jumlah Perolehan Suara Sah Parpol dalam Pemilu 2014. Jakarta: Komisi Pemilihan Umum, 2016.

Karimah, Kismiyati\& Wahyudi, Uud, Filsafatdan Etika Komunikasi. $\quad$ Bandung: Widya Padjadjaran, 2010.

Kasiram, Moh. (2008.) Metodologi Penelitian Kualitatif Kuantitatif. Malang:UIN Malang Press.

Kencana Syafiie, Inu. (2003). Teori Dan Analisis Politik Pemerintahan. Jakarta: PT.Perca.

Koirudin. (2008). Partai Politik Dan Agenda Transisi Demokrasi. Yogyakarta: Pustaka Pelajar.

Komisi Pemilihan Umum. Rekapitulasi Jumlah Perolehan Suara Sah Parpol dalam

Made Pirdata, Made. Perencanaan Pendidikan Partisipasi dengan

Pendekatan system. Jakarta cipta, 2016.

Muhammad, Ahmad Al-'Aththar. (2012). The Magic of Communication, Jakarta: Zaman.

Mulyana, Deddy. (2005). Ilmu Komunikasi Suatu Pengantar. Bandung: Remaja Rosdakarya.

Nadir, Ahmad. (2005). Pilkada Lagsung Dan Masa Depan Demokrasi. Malang: Averroes Press.

Nursanjaya, Amiruddin. (2002). Prosedur Penelitian Suatu Pendekatan Praktek, Jakarta: Rineka Cipta.

Nasution, Zulakrimin. (2007). Komunikasi Pembangunan Pengenalan Teori dan Penerapannya,Edisi Revisi. Jakarta: PT. RajaGrafindo Jakarta.

Nawawi, Hadar dan Martini, Mimi. (2009). Penelitian Terpadu . Yogyakarta: Gajah Mada University Perss.

Nawawi, Hadari.( 2009). Metode Penelitian Sosial. Yogyakarta: UGM-Press.

Nursal, Adman. Political Marketing. Jakarta: PT Gramedia Pustaka Utama 2010.

Pusat Pembinaan dan Pengembangan Bahasa, Kamus Besar Bahasa Indonesia Edisi Ketiga,Jakarta: Cipta Pustaka, 2009.

Pemerintahan, Kabupaten Labuhanbatu Selatan. Sejarah Labusel (Kota Pinang: Pemkab. Labusel, 2017.

Pemerintahan,Kabupaten Labuhanbatu, Statistik dalam angka kab. Labusel 2017. Kota Pinang : Pemkab. Labusel, 2017. 
Rahmat, Jalaluddin. (2008). Psikologi komunikasi, Bandung: Remaja rosda karya.

Rudianto. (2021). Presidential Election and the Battle of Online Media Discourse in Indonesia. Budapest International Research and Critics Institute-Journal (BIRCIJournal). P. 441-449.

Purwanto, Ngalim. (2000). Administrasi Dan Supervisi Pendidikan. Bandung: Remaja Rosdakarya.

Subagyo, Joko. (2009). Metoe Penelitian Dalam Teori dan Praktek, Jakarta: P.T Rineka Cipta. Sugiono. (2008). Memahami penelitian kualitatif. Jakarta: Alfabeta.

Santoso, Sastropoetro. (2015). Partisipasi, Komunikasi, Persuasi dan Disiplin dalam Pembangunan Nasional. Bandung: Rosdakarya.

Suranto, Aw. (2015). Komunikasi Sosial Budaya. Jakarta : Raja Grafindo Persada.

Vardiansyah, Dani. (2008). Filsafat Ilmu Komunikasi Suatu Pengantar. Jakarta:PT Indeks.

Zuhri. (2014). Peranan Sekolah dalam Proses Sosialisasi Politik Studi Penelitian Terhadap Siswa SMA Negeri 2 Semarang. Semarang: Program Studi Magister Ilmu Politik Universitas Diponegoro.

Zulkarimen Nasution. (2007). Komunikasi Pembangunan Pengenalan Teori Dan Penerapannya, Edisi Revisi. Jakarta: PT. Raja Grafindo Jakarta. 